\title{
After the Reforms: An Analysis of the Factors Associated with the Use of Legal Services in Child Welfare Proceedings in Ireland
}

\author{
${ }^{*}$ Edel Walsh ${ }^{1}$ \\ Aileen Murphy ${ }^{1}$ \\ Carmel Halton ${ }^{2}$ \\ Gill Harold $^{2}$
}

\begin{abstract}
'Ilept. of Cconomics, Cork Iniversity Businesss School, Iniversity Collegege C'ork, Cork, Irelind

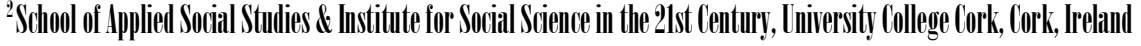

Against the backdrop of austerity measures and public sector reforms in Ireland, this paper examined legal costs incurred in child welfare proceedings by the State Child and Family Agency Tusla, using a need-based allocation model. The direct financial costs of engaging with legal services, necessitated by the adversarial nature of child welfare proceedings, were scrutinized to determine if resources were allocated based on need. Adopting a cross-sectional research design, secondary data (obtained from the organization's financial billing system. $n$ =1032) were employed in an econometric analysis examining the factors influencing variations in Tusla's legal expenditure. The dependent variable was total amount billed by legal firm per observation and the independent variables included type of legal activity involved (a proxy for need), geographical location and type of legal personnel (supply factor). Type of legal personnel, volume and type of legal activity have significant positive effects on legal spend. Administrative area does not significantly affect spending on legal services. We found that engagement with legal services, demanded by the adversarial nature of child welfare proceedings, has considerable cost implications; however, does seem to be allocated on the basis of need. The findings can be employed to increase the organization's awareness of costs.

Keywords: Child protection, legal expenditure, public sector, Tusla, Ireland

JEL:H83, J13, P36
\end{abstract}

Like many other European countries Ireland's economy suffered a sharp decline following the collapse of financial systems in 2007/2008 and ensuing "Great Recession", which persisted until 2013. Prior to this, during the Irish Celtic Tiger years, there was an abundance of public resources but efficiency improvement in the public sector was not prioritised (Irish Department of Finance [IDF], 2010). However, in light of the global financial crisis and subsequent recession, policy shifted swiftly; austerity budgets and expenditure cut backs were put in place and public sector reform commenced (MacCarthaigh, 2017; Organisation for Economic Cooperation and Development [OECD], 2010).

In addition to the global financial crisis, a combination of domestic factors also contributed to Ireland's economic decline. These include, weak regulation of financial institutions, weak state capa- 
International Journal of Management, Economics and Social Sciences

city and pro-cyclical fiscal policies adopted since 1990s (Honohan et al., 2010; Houses of the Oireachtas, 2016; IDF, 2010; Regling and Watson, 2010). The result, according to the International Monetary Fund (IMF) was "the costliest banking crisis in advanced economies since at least the Great Depression" (Laeven and Valencia, 2012), whereby state bank guarantees were implemented, and a "bailout" Ioan was acquired from the Troika of the International Monetary Fund, European Commission and European Central Bank in 2010. Between 2008 and 2016 the Irish economy underwent a period of massive fiscal adjustments, involving unprecedented cutbacks and reform of Irish public services (MacCarthaigh, 2017). To reduce the gap between government revenue and expenditure the Government reduced the public sector pay bill, this was achieved by reducing social transfers, pay and pensions, a recruitment freeze and untargeted early retirement schemes; as well as introducing new taxes/charges (Barry and Conroy, 2013). In essence the state was shrunk in an orderly manner while simultaneously the demand for public services was increasing (MacCarthaigh, 2017). This left little room for investment or future planning which has resulted in major policy problems including rising poverty levels, economic stress, homelessness and persistent excess budgets in key areas such as health and welfare (Williams, Whelan and Bertrand Maître, 2017).

The international reforms in response to the "Great Financial Crisis" have been labelled post-New Public Management (post-NPM), the paradigm of which characterizes the trend towards whole-ofgovernment reform programs witnessed internationally (Christensen and Lægreid, 2011). These reforms are associated with (re)centralization of control (political and administrative) coupled with a greater attention on coordination, collaboration and joined-up outcomes (Chapman and Duncan, 2007; De Vries and Nemec, 2013; Goldfinch and Wallis, 2010; Jun, 2009; Lodge and Gill, 2011). According to MacCarthaigh (2017) the post-NPM paradigm characterizes the cut back management and Irish reform agenda which saw an overhaul of the public administration system, which had been traditionally considered a "laggard" when compared to its counterparts internationally who had experienced the "New Public Management (NPM)" revolution after the 1970 s oil crises etc.

In reality public sector reform is a tangled affair involving various strategies of centralization and decentralization which are switched between and used in tandem as required (MacCarthaigh, 2017). In reforming the public sector in Ireland, innovative efforts were made to "renew" the civil/public service, while having vision and asking bold questions so as to established greater accountability for decision making, a new management and accountability regime. While Ireland had been a laggard with respect to NPM, the reforms implemented aim to improve efficiency and performance and do "better with less" (Smith, 2019). The reforms go beyond the dated New Public Management (NPM) type reforms towards the hybrid post-New Public Management model of reform. This has brought about new coordination and collaboration measures in the search for standardization, reassertion of political control and renewed attention to public service values (MacCarthaigh, 2017), which aim to strengthen coordination 


\section{Walsh et al.}

through more centralized/collaborative capacity (Lodge and Gill, 2011).

The organization of children's services is one area which experienced substantial reform through the Program for Government (Government of Ireland [GOI], 2011). Children and family services was removed from the Health Services Executive (Department of Health) and a dedicated, expanded child welfare and protection agency was established i.e., Tusla.

\section{The Child and Family Agency - Tusla}

Tusla is responsible for improving wellbeing and outcomes for children and operates under the Child and Family Agency Act (CFAA), 2013 (Tusla, 2018). It is an independent legal entity, comprising of the Health Service Executive (HSE) Children and Family Services, the Family Support Agency (FSA) and the National Educational Welfare Board (NEWB), as well as incorporating some psychological services and a range of services responding to domestic, sexual and gender-based violence (Tusla, 2018). The main motivation for moving the social work service away from the health services was "to emancipate our child protection and welfare services from the monolith of the health services where for too long in the past they were lost and rudderless" according to the Minster for Children (Irish Department of Children and Youth Affairs [IDCYA], 2013a). Key features of the reform were leadership, enhanced accountability and more efficient interdisciplinary and inter-agency working (IDCYA, 2013b). As the formation of this new agency, with separate a legal entity, and the new Department of Children and Youth Affairs (IDCYA), was during the time of austerity, this major reform had minimal transition funding and was led by staff from the Department and HSE. Furthermore, the decision makers in the establishment had experience of delivering the service previously and would have responsibility for managing the organization going forward, a rarity in public sector reforms (Irish Institute of Public Administration [IPA], 2017). However, as identified by Buckley and Burns (2015), there were significant threats to the reform and its ambition given the period of austerity and retrenchment of public services that were on going at the time. In particular, would the change management process and the delivery of the services be adequately resourced (Buckley and Burns, 2015). The establishment of Tusla was challenging, involving 4,000 staff and a budget of over $€ 600$

million and is considered to have been relatively successful (IPA, 2017). Tusla now has over 4,000 employees and an annual operational budget of over $€ 750$ million (Tusla, 2018).

\section{Public Sector Reform and Child Welfare Services}

Since Tusla was established, Ireland has emerged from the "Great Recession" and economic indicators such as Gross Domestic Production (GDP) indicate that the economy is growing again, unemployment is falling and tax receipts are increasing (Irish Central Statistics Office [ICSO], 2018). Nonetheless, the backdrop of austerity persists. And so, in delivering public services, managers are 
encouraged to be economical, efficient and effective, whilst organizations aim to be responsive to the needs of its clients. In doing so, managers are expected to be accountable, tighter financial controls is a common means to ensure transparency (McKevitt and Lawton, 1994). It is important, however, that as managers are being held accountable, they have control over the factors that contribute to the results, which includes quality of information (Dunsire, Hartley and Parker, 1994). Public sector accountability has been a key area for discussion and action over the last few decades (Hopwood, 1994). This includes efforts to identify and eliminate inefficiency, unprofitability, waste and the lack of cost effectiveness. While this may have been previously on the agenda elsewhere it is now clear, postrecession and austerity, that it was not to the fore in the Irish public sector, but it needs to be. Given its newness, Tusla presents an interesting case study to investigate accountability. This research examines the economic contexts in which legal services are utilised by social work professionals in the Irish child and family welfare service - Tusla.

According to McKevitt and Lawton (1994) the value placed on public services is conditioned by historical and cultural tradition as much as it is constrained by current economic and political considerations. Furthermore, reforming the delivery of public services rests on quite a deep and often implicit assumption with regards to the relationship between the State and its citizens (McKevitt and Lawton, 1994). These sentiments are central when considering the Irish child protection system in light of child abuse scandals and revelations regarding poor practices (see Buckley and Burns (2015) and Smith (2019) for a detailed account of Child Welfare and Protection in Ireland). In the context of public sector reform post-2008, and a "do better with less" approach (Smith, 2019), child policies have become increasingly results driven, and the policy agenda appears to have shifted to a universal approach to the provision of early years services. The economic rationale behind spending/investment in early years is that it yields benefits in the future in the form of better health, higher educational attainment and lower anti-social behavior (Smith, 2019).

\section{Role of Legal Services in Child Welfare Proceedings}

It is recognized that the child welfare and protection system in Ireland is largely adversarial and child protection and welfare practice are viewed as the most legally intensive speciality within the social work profession. Therefore, social work increasingly brings practitioners into contact with the legal system. The court provides the context for proceedings, and within that setting all participants are expected to be conversant in the dominant legal discourse. Over the last 25 years the legal profession and the courts have come to play an increasingly prominent role in the handling of child welfare cases in Ireland. Despite this, very little research has been carried out on the interface between social services and the legal system (Burns, O'Mahony, Shore and Parkes, 2018).

As mentioned above, against a backdrop of austerity measures in recent years, public expenditure 


\section{Walsh et al.}

in Ireland has come under intense scrutiny. Social work practitioners in Tusla work in a public service context where procurement requirements and systems of accountability need to comply with regulatory controls enshrined in legislation and operated by financial controllers. While Tusla social workers are vested with responsibility to protect the welfare of children who are engaging with the Agency's services, nonetheless the work they carry out can be significantly influenced and shaped by their organisation's approach to resource allocation. Here we examine if legal services (a significant and expensive resource for the Agency) is allocated based on need, or if other factors influence spend on legal services. The remainder of this paper is structured as follows. Next, we present a review of the economics literature in the area of child protection and welfare. The theoretical framework and methodology employed are then outlined. The main findings are then presented before concluding with a discussion of the study's limitations and avenues for future research.

\section{LITERATURE REVIEW}

Literature and general commentary on the economics of child protection and welfare is sparse and rarely goes beyond the disaggregation of expenditure data. This is not surprising given the difficulty associated with measuring qualitative outcomes, which are sometimes intangible, for example, happiness and wellbeing in adult life following the experience of childhood neglect and removal from the family of origin. Longitudinal research is required to address this gap, engaging with children in care through to adulthood.

An exception is Gustavsson and Segal (1994), who have referred to the cost of neglect in another sense, that is the idea that the overall benefits to society of caring for children today, results in a healthy and productive workforce for the future. Furthermore, there are social and economic costs, including for example, high school dropout, social services, and juvenile detention, amongst others and ensuring preventive services are in place so that social problems don't go untreated and become very costly over time (Gustavsson and Segal, 1994). While the cost effectiveness of preventive early intervention is foregrounded, they also state that preventing social problems through early intervention is key to improving the overall wellbeing of children (Gustavsson and Segal, 1994). Similarly, and from an Irish context, Gilligan (1996) asserts that the child care agenda should not be dominated by a preoccupation with child protection but that it should also retain a balance which favors prevention and family support.

There is a dearth of literature and general commentary on the cost effectiveness of child protection and welfare. This limitation is often owing to difficulties in measuring and collecting qualitative outcomes. As is the case in previous literature, the analysis in this research is confined to examining expenditure data arising from the use of legal services in child welfare proceedings and the factors affecting same. 


\section{-Theoretical Framework}

In the midst of the "Great Recession" and resultant austerity, health and social care costs are escalating (OECD, 2018) owing to demographic and socio-economic changes worldwide. A proportion of the latter is as a result of austerity measures and cuts. While Ireland's economy has begun to grow, it is facing major social issues that undoubtedly will place further pressure on public services. Thus, in going forward it is imperative that the cut-backs and austerity were not in vain and we do not revert to the old ways with lack of accountability, inefficiency and waste. While Tusla is a new organization, created during the reforms and austerity, it should be an exemplar for delivering public service provision devoid of inefficiencies, waste etc.

Nevertheless, public service organizations, including Tusla, need to examine and analyze their costs and pursue cost containment in order to respond to the requirements for greater public accountability. This refers to the process of controlling organizational costs within a specified budget, or restraining expenditures to meet organizational or project financial targets. Cost containment is an important management function and many interventions have been employed internationally to contain, manage and reduce costs (Pane and Taliaferro, 1994).

Before implementing cost containment measures however, it is important that there is an understanding and awareness of the costs and their drivers. Cost awareness focuses the organization and its employees on costs. Increased awareness of what the costs are, the process available for containing them, how they can be managed and by whom are fundamental matters pertaining to service planning and future development. Furthermore, costs should be monitored for a period so management is aware how much, where, when and why money is being spent. After which conceptual and physical acts to limit unnecessary spending through planned and practical use of resources for maximum productivity can be implemented.

Furthermore, for not-for-profit and government agencies like Tusla, whose primary objective is not profit maximization, attention needs to be paid to what value is derived from the resources employed. In health care "value for money" concepts have been debated, defined, measured and employed for decades (Porter, 1985; Porter and Teisbers, 2006). Examining "value for money" in social care however, is less prevalent and perhaps impeded by the onerous task of measuring and valuing outcomes. White, Hodges and Greenslade (2015) propose that value for money can be assessed at different points in the chain (see Figure 1) using the 3Es: economy, efficiency and effectiveness.

This study employs a need-based allocation model, populated with routinely collected data, to empirically examine value for money at the economy point on the value for money chain. To so, we examine expenditure data arising from the use of legal services in child welfare proceedings and the factors affecting same in Tusla through the use of econometric analysis techniques. In public not-forprofit organizations such as Tusla, in the wake of austerity and reform, resources are scarce. The me- 


\section{Walsh et al.}

ans by which these scarce resources are allocated is another complex and challenging exercise for public agencies. A key policy objective in most publicly financed systems is to allocate resources according to need (Kephart and Asada, 2009). To that end, we examine the existing use of needbased resource allocation models within the health and social care arenas.

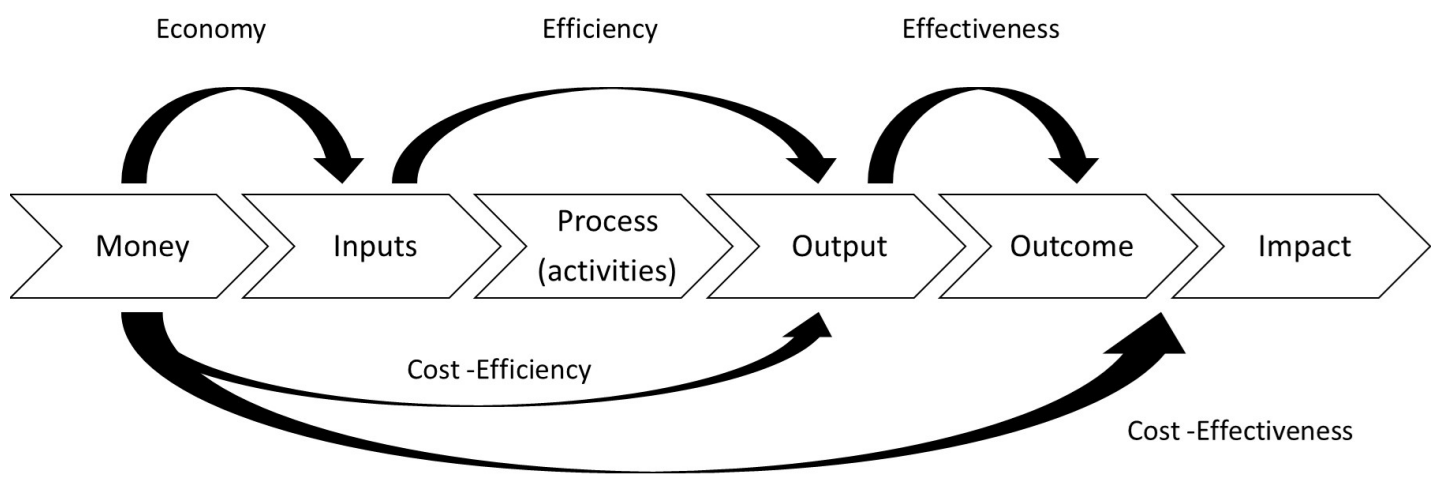

Source: Adapted from White et al. (2015)

Figure 1. Assessing Value for Money Chain

\section{Need-Based Resource Allocation Models}

Need-based resource allocation models are widely used in countries to allocate health care resources between regions (Kephart and Asada, 2009) or in determining primary medical care capitation payments (Hutchison et al., 2000). However, these models have also been used in allocating funding to schools (Ross and Levacic, 1999) and social housing (Whitehead, 1991). Need-based models support the idea that resources are distributed on the basis of relative needs for (health) care or the service in question. Striving for equitable systems, countries rely on accurate data in order to allocate resources based on need. In the distribution of resources in health care, information on age, gender, socio-economic status and health status are commonly used as need indicators. However, no gold standard has been agreed to state which need indicators should be included in these models (Kephart and Asada, 2009).

The analysis in this paper is based on the notion that the allocation of resources to individuals must be based on need. In allocating resources to legal representation, we examine the context in which need plays a part in this for Tusla. The data used in this paper include a number of "Legal factors" which represent/proxy the need to engage with the legal system and the need for legal representation. Existing research examining childcare proceedings in Ireland points to regional variations in court practices (Parkes et al, 2015; Perry, 2017). Examining child care law reporting in Ireland, Coulter (2015) finds regional variations in the types of applications made and the outcomes of cases at 
District Courts. In following a need-based model there are implications for resource allocation if geographical region is found to be correlated with expenditure on legal services.

Following a need-based model to examine legal expenditure in child welfare proceedings, a number of key available indicators were identified (based on existing studies) for inclusion in the model. These need indicators include legal factors (proxy for legal need), geographical area (to capture regional variation), type of legal personnel (supply side factor). The following hypotheses are investigated:

$\mathrm{H}_{1}$ : Legal factors positively influence legal spend.

$\mathrm{H}_{2}$ : Geographical area positively impacts legal spend.

$\mathrm{H}_{3}$ : Experience of legal personnel involved positively influences legal spend.

\section{METHODOLOGY}

In the context of the adversarial nature of child welfare proceedings we investigated the cost implications of engaging with legal services on the basis of need, using a need-based allocation model. To do so, an econometric analysis of legal, geographical and supply factors influencing variations in Tusla's legal spend was performed. The sole source of data available for the economic analysis of factors affecting legal spend was a financial system, the primary aim of which was to record data from invoices and legal activity pertaining to said invoices (AXLE, 2016). Standard practice is that invoices are paid to "member firms" who are legal firms that provide legal representation on behalf of Tusla. These firms are selected through a tendering process. A "matter" is the unit of analysis on this system and can include multiple children from the same family and include multiple legal activities. This analysis was limited to matters opened between 2014 and August 2016 and also closed in that same period (closed matters refer to those for which a final bill has been issued; $n=$ 1032). Nevertheless, the breadth of legal activities included in the analysis was substantial, and there was good geographical representation. Regression analysis was carried out to investigate factors influencing total spend by Tusla per matter (where total spend per matter represents legal expenditure by Tusla to member firms).

Prior to conducting the econometric analysis, the data is described and summarized (Table 1-see Appendix-1). Following this an econometric analysis is undertaken to estimate the following equation that represents a need-based allocation model:

$$
\text { lnMemberFirmBill }=\alpha+\beta_{1} \text { AdminArea }+\beta_{2} \text { FeeEarnerType }+\beta_{3} \text { LegalCategory }+\mu \quad \text { Eq. (1) }
$$

where:

InMemberFirmBill = log member firm bill in euros (continuous variables, euros). 


\section{Walsh et al.}

AdminArea $=$ administrative area $(4$ binary variables representing each administrative area; Dublin North East, Dublin-Mid-Leinster, South, and West, where 1 indicates presence and 0 absence).

FeeEarnerType $=$ Legal professional $(3$ binary variables representing each type of earner; Partner, Solicitor and Associate, where 1 indicates presence and 0 absence).

LegalCategory = legal category (23 binary variables representing each type of legal activity. See Table 1 for list)

$\alpha=$ constant

$\beta=$ coefficient

$\mu=$ error term

To capture need, in the absence of client details, a proxy measure summarizing the legal complexity of matters, in terms of range and quantity of legal activities, was employed. To do so count variables representing each type of legal activity and the amount of these activities per matter were created. Other factors that may influence resource allocation are geography (proximity to political and organizational hubs) and supply factors. With regards to geographic area we included administration area that refers to one of four areas in Ireland (as defined by Tusla): Dublin North East, Dublin Mid Leinster, South, or West (dummy variable for each). The South and West would be further from the organizational head-quarters and Government and would include more rural areas. With regards to supply factors, we included fee-earner type to capture experience of legal personnel involved and refer to the presence of a partner, solicitor, and/or associate working on the matter (dummy variable for each).

Equation 1 was estimated via Ordinary Least Squares (OLS) regression technique using the statistical software package STATA Version 14 (StataCorp, 2014). The simplest regression equation is; $y=\alpha+\beta x$, where " $y$ " is the dependent variable (plotted on the vertical axis), " $x$ " is the independent variable (plotted on the horizontal axis), and " $\alpha$ " is the constant or intercept, " $\beta$ " is the estimated effect also known as the regression coefficient (Greenhalgh, 1997). A multiple regression (a more complex mathematical equation) allows the target variable to be predicted from two or more independent variables (Greenhalgh, 1997).

\section{-Dependent Variable}

The study regression has a unique dependent variable: euro amounts of total member firms invoice/bill (InMemberFirmBill). This is a continuous variable measured in euro amounts that member firms have billed Tusla for each matter. As is often the case with continuous variables the raw data were not normally distributed, they were skewed (see Figure 2). That is to say, the distribution is asymmetrical, 
therefore is non-normally distributed. In this situation where the variables are right-skewed, that is, have a long tail at the high end; most of the observations occur at lower values. Consequently, the re-

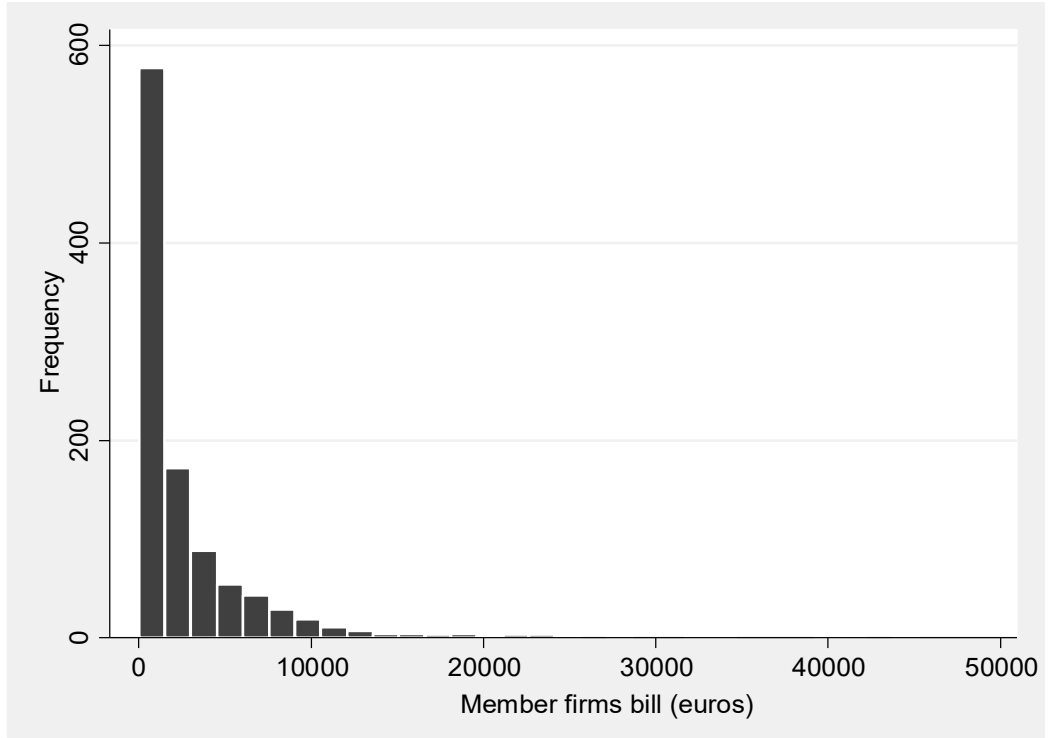

Source: AXLE (2016)

Figure 2. Chain Histogram Total Amount Billed

gression may be influenced a great deal by one or a few of the cases at the high end (outliers). Taking the log of the variable can reduce or eliminate the skew, improving the model. Furthermore, using the log of the variable makes substantive sense with a dependent variable such as we have here, which we tend to think of in multiplicative terms rather than additive ones. To facilitate the OLS regression analysis, therefore, the dependent variable was logged (see In notation on Equation 1). The OLS regression assumes that the errors, as estimated by the residuals, are normally distributed. Histograms are presented to show the proportional frequency of the variables (see Figures 2 and 3). The average log total amount billed was $€ 7.09$ (Standard deviation 1.399). After the variables are logged there is symmetry in the data.

\section{-Independent Variables}

A number of independent variables were employed in the regression analysis to inform the need-based allocation model. As mentioned above, legal need is measure using a proxy variable that captures range and quantity of legal activity. To do this, 23 count variables were created, each capturing type of legal activity (see Figure 4) and the amount of these activities per matter. In terms of matter complexity, the most frequently occurring activities were Section 17 Interim Care Order (52\%), Section 18 Care Order (40\%), General Advice (30\%), Emergency Care Order (28\%), and Supervision Orders (28\%). Figure 5 illustrates the variation in most frequently occurring activities (Section 17 Interim Care 
Order, Section 16 Care Order, General Advice, Emergency Care Order, and Supervision Orders) by administrative area.

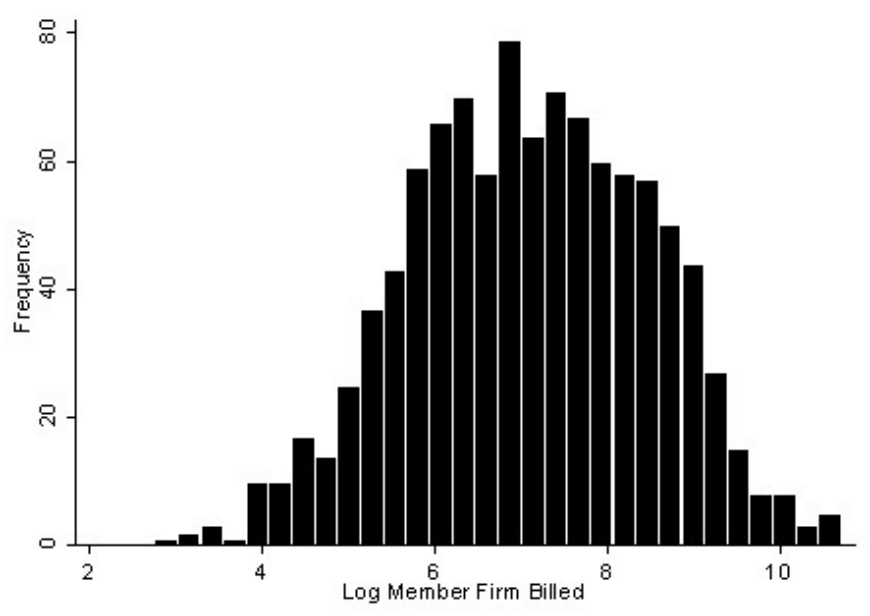

Source: AXLE (2016)

Figure 3. Histogram Total Amount Billed (Logged)

With regards to geographical area, 33 percent of matters analyzed related to Dublin Mid-Leinster area; 27 percent West area; 22 percent Dublin North East and the remaining 19 percent the South. With regards to fee-earner type, 61 percent of matters had partner time billed; 54 percent had associate time, and 33 percent had solicitors. The descriptive statistics for all variables are presented in Table 1.

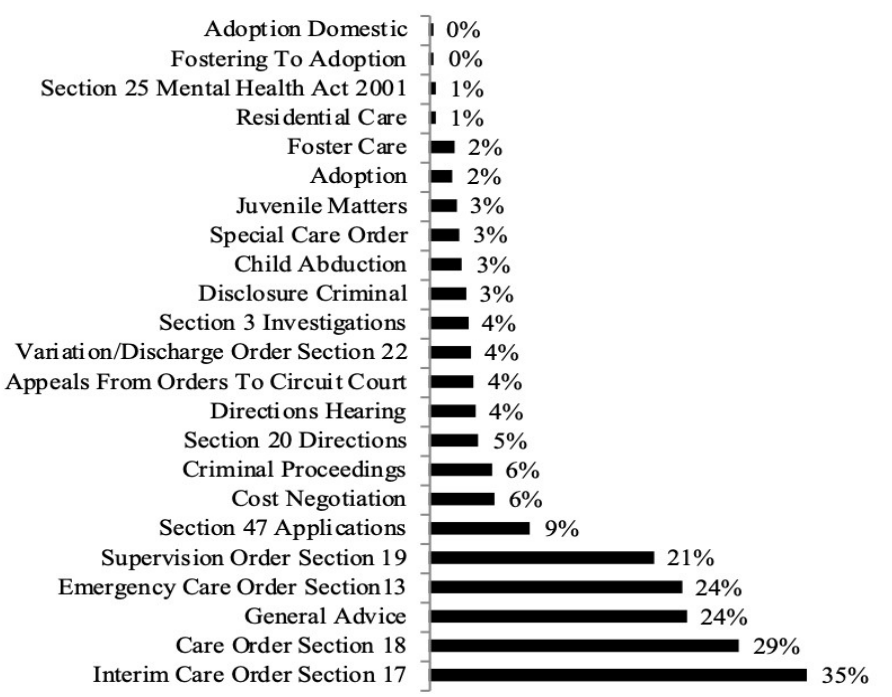

Source: AXLE (2016)

Figure 4. Legal Activity 


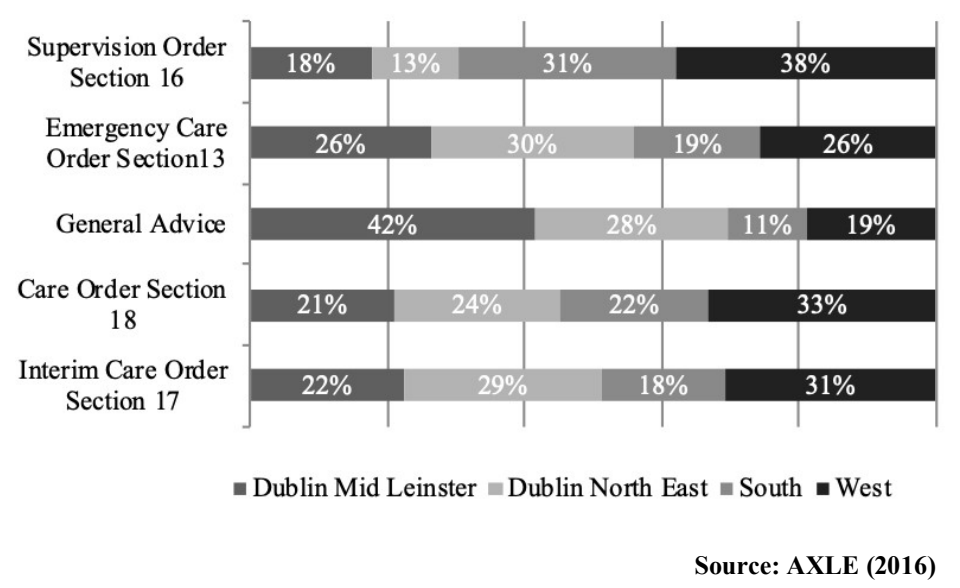

Figure 5. Legal Activity by Region (Top 5 Types of Legal Activity)

\section{RESULTS}

The regression results are presented in Table 2 (see Appendix-II). The results revealed that the independent variables explain 50 percent of the variation in total amount billed. The results show that over the period January 2014 to August 2016 a number of factors were statistically significant at 1 percent, 5 percent and 10 percent levels. The most significant results are those which are statistically significant at 1 percent level. With regards to legal activity, Adoption (125\%), Adoption Domestic (166\%), Care Order Section 18 (47\%), Child Abduction (48\%), Criminal Proceedings (71\%), Disclosure Criminal (53\%), Emergency Care Order (22\%), General Advice (13\%), Interim Care Order (60\%), Section 25 Mental Health Act 2001 (91\%), Section 3 Investigations (33\%), Special Care Order (57\%), Supervision Care Order Section 16 (50\%), Variation/Discharge Order Section 22 (40\%) all individually increased the total amount billed per matter, holding all else constant. These results allow us to accept our first hypothesis that Legal factors positively influence legal spend. Administration area was insignificant in explaining total amount billed. Therefore, we cannot accept our second hypothesis that Geographical area positively impacts legal spend. Having a fee-earning partner increased the total amount billed per matter by 42 percent, holding all else constant. Similarly, having a fee-earning associate increased the total amount billed per matter by 21 percent, holding all else constant. In conclusion, we can accept our third hypothesis that experience of legal personnel involved positively influences legal spend.

For robustness, the analysis was repeated using a second dependent variable (time billed in hours) and similar results were found (results available from the authors on request).

\section{DISCUSSION}

An econometric analysis is performed to investigate the factors affecting spend on legal services by 


\section{Walsh et al.}

the Child and Family Agency - Tusla in Ireland, in the wake of the "Great Recession", subsequent public sector reform and austerity. Thereby, investigating the direct financial costs of engaging with legal services, as necessitated by the adversarial nature of child welfare proceedings. The analysis demonstrates that the type of legal personnel (fee-earner type who bills for the matter), volume of legal activity, and type of legal activity have significant positive effects on legal spend. With regards to type of legal activity (and frequency of their occurrence) the following are found to have statistically significant positive relationships with euro amount billed: Adoption, Adoption domestic, Care Order Section 18, Child Abduction, Criminal Proceedings, Disclosure Criminal, Emergency Care Order Section 13, General Advice, Interim Care Order Section 17, Section 25 Mental Health Act 2001, Section 3 Investigations, Special Care Order, Supervision Care Order Section 19, and Variation/Discharge Order Section 22. That is to say, these types of legal activities, when present, increase spending on legal services. The analyses reveal that administrative area does not affect spending on legal services.

\section{CONCLUSION}

The results of this analysis focus on the "economy" links in the value for money chain and can be employed to increase the organization's awareness on costs post public sector reform in child welfare services. To do so the study employs a need-based allocation model to examine expenditure data arising from the use of legal services in child welfare proceedings and the factors affecting same. Thereby this study examines if legal services are allocated based on need or some other factors. Results reveal type of legal personnel, volume of legal activity, and type of legal activity, have significant positive effects on legal spend. Therefore, suggesting that resource allocation is based on need (captured in legal activity) but also influenced by supply factors, i.e., more experienced the legal professional engaged on the matter the higher the costs. Furthermore, the results reveal that engagement with legal services necessitated by the adversarial nature of child welfare proceedings has considerable cost implications. However, while substantial, the costs do appear to be proportional to the legal activity, which should negate inefficiency and waste. Therefore, suggesting that resource allocation is based on need.

\section{IMPLICATIONS}

As well as adding to the discourse on public sector reform and allocation of scarce public resources, this novel research has implications for the State Child and Family agency - Tusla as well as national and international public bodies. Firstly, the empirical results reveal an increase in legal activities and complexity of same is associated with an increase in legal spend in Tusla. This is encouraging and suggests that spending on legal services is based on need. However, supply factors also influence 
International Journal of Management, Economics and Social Sciences

spend, the more experienced the legal professional engaged the grater the legal spend. From a practical perspective this is not surprising. However, Tusla may wish to examine service level agreements with private legal providers, for example, ensure the quota they place on partner involvement is appropriate. In addition, the results of this study could be employed in examining the cost effectiveness of future reforms via interventions, policies or programmes in Tusla to inform future investment decisions. These analyses would compare outcomes and impacts to cost further along the value for money chain; leveraging on the examination of costs to evaluating cost efficiency and cost effectiveness of specific interventions. Such tools are also a useful means of restraint as they can constrain expenditures, actions and polices (Hopwood, 1994); which is necessary when resources are scarce.

From a wider perspective, we acknowledged previously that examining "value for money" in social care is burdensome and less prevalent than the health care sector. This study empirically demonstrates how a need-based allocation model, that is regularly employed in other sectors, can be employed using routinely collected data to examine value for money at the economy point on the value for money chain (see Figure 1) for organisations like Tusla. This is beneficial as the economic costs can be made more visible than the social and political, and using accounting tools to examine costs is important as it provides a record of the choices and actions of an organisation. This can both reflect and influence public debate (Hopwood, 1994). Therefore, the study results may increase awareness on costs both in Tusla and also in other public sector bodies and departments. This is timely, as while Ireland is technically out of recession, restrained public expenditure is advocated to avoid future fiscal crises (Irish Fiscal Advisory Council, 2018).

\section{LIMITATIONS AND FUTURE DIRECTIONS}

The analysis presented in this research is subject to a number of limitations owing to the data employed. Firstly, only closed matters were analysed (closed matters refer to those for which a final bill has been issued), which may introduce a bias as ongoing matters may have a greater degree of complexity not captured amongst closed matters. Secondly, despite having incentive structures in place for member firms to input data onto the system, significant gaps (i.e., missing data) are evident in the dataset, which placed constraints on the variables that could be included. Finally, we acknowledge that the analysis is not explaining all of the variation in spend on legal services. However, the analysis is limited to the routinely collected data provided from the financial system by Tusla. We appreciate that this system is a management information system of which the primary purpose is to collate information for billing purposes. Tusla indicated that incentive structures are in place for member firms to input financial data onto the system. However, given the significant data gaps evident in the dataset, this research suggests that greater fidelity in terms of implementation is requir- 


\section{Walsh et al.}

ed throughout the system.

This study relies on routinely collected financial data which is employed in a need-based allocation model to examine expenditure data arising from the use of legal services in child welfare proceedings and the factors affecting same. While employing routine data for such matters may not be ideal, it is often the best available data in practice. We would recommend that public bodies such as Tusla should have appropriate incentive structures in place to ensure data gaps are minimised, data capturing opportunities are maximised, and fidelity arrangements are in place. In addition, to completely assess value for money, we cannot solely rely on cost data. While measuring and evaluating outcomes in this arena is challenging, it is valuable with regards to examining the quality of child protection and welfare services and in terms of reviewing whether spending is generating value for money and informing decisions. Such information, if of sufficient quality, could improve organisational performance (Dunsire et al., 1994). Such analysis could be performed by using a longitudinal approach to data collection. This would enable as well as the development and data collection of data of measures for on qualitative outcomes. This will also facilitate longer term evaluation of child policies focusing on early years that have been implemented since public sector reform and the financial crisis.

\section{REFERENCES}

AXLE. (2016). Information and Billing System. Arthur Cox Consultancy Services.

Barry, U. \& Conroy, P. (2013). Ireland in Crisis 2008-2012: Women, austerity and inequality Karamessini, In M. \& Rubery, J. (Eds.), Women and austerity: The economic crisis and the future for gender equality. London: Routledge.

Buckley, H. \& Burns, K. (2015). Child welfare and protection in Ireland: Déjà vu all over again Social work in Ireland: Continuities and changes. London: Palgrave Macmillan.

Burns, K. O'Mahony, C., Shore, C., \& Parkes, A. (2018). What social workers talk about when they talk about child care proceedings in the District Court in Ireland. Child and Family Social Work. 23(1): 113-121.

Chapman, J. \& Duncan, G. (2007). Is there now a new "New Zealand model"? Public Management Review. 9(1): 1-25.

Christensen, T. \& Lægreid, P. (2011). Post-NPM reforms: Whole of government approaches as a new trend. In S. Groeneveld \& S. V. Walle (Ed.), New steering concepts in public management (pp.11-24). Emerald Group Publishing Limited,

Coulter, C. (2015). Childcare law reporting project. Retrieved 14 March 2018 from https://www.childlawproject.ie/wpcontent/uploads/2015/11/CCLRP-Full-final-report_FINAL2.pdf.

De Vries, M. \& Nemec, J. (2013). Public sector reform: An overview of recent literature and research on NPM and alternative paths. International Journal of Public Sector Management. 26(1): 4-16.

Dunsire, A., Hartley, K. \& Parker, D. (1994). Organizational status and performance: Summary of the findings. In D. McKevitt \& A. Lawton (Eds.), Public sector management: Theory, critique and practice. London: Thousand Oaks, Sage.

Gilligan, R. (1996). Irish child care services in the 1990s: The Child Care Act 1991 and other developments'. In: M. Hill and J. Aldgate (Eds.), Child Welfare Services: Developments in Law, Policy, Practice and Research. London: Jessica Kingsley Publishers.

Goldfinch, S. \& Wallis, J. (2010). Two myths of convergence in public management reform. Public Administration. 88(4): 10991115.

Government of Ireland. (2011). Programme for government. Retrieved 5 December 2018 from, https://www.taoiseach.gov.ie/eng/Work_Of_The_Department /Programme_for_Government/ Programme_for_Government_ 2 011-2016.pdf.

Gustavsson, N. S. \& Segal, E. A. (1994). Critical issues in child welfare. CA: Thousand Oaks, Sage.

Greenhalgh, T. (1997). How to read a paper: Statistics for the non-statistician. I: Different types of data need different statistical tests. BMJ. 315(7104): 364-366.

Honohan, P., Donovan, D., Gorecki, P. \& Mottiar, R. (2010). The Irish banking crisis: Regulatory and financial stability policy. MPRA Paper No. 24896. Retrieved 6 December 2018, from https://mpra.ub.uni-muenchen.de/24896.

Hopwood, A. (1994). Accounting and the Pursuit of Efficiency. In D. McKevitt \& A. Lawton (Eds.), Public sector management: theory, critique and practice. London: Thousand Oaks, Sage.

Houses of the Oireachtas. (2016). Joint committee of inquiry into the banking crisis. Retrieved 6 December 2018, from https:// 
inquiries. oireachtas. ie/banking.

Hutchison, B., Hurley, J., Birch, S., Lomas, J., Walter, S. D., Eyles, J. \& Stratford-Devai, F. (2000). Needs-based primary medical care capitation: development and evaluation of alternative approaches. Health Care Management Science. 3(2): 8999.

Irish Fiscal Advisory Council. (2018). Fiscal assessment report. Retrieved 27 March 2019, from https://www. fiscalcouncil.ie/wpcontent/uploads/2018/11/Fiscal-Assessment-Report-November-2018-Final.pdf

Irish Central Statistics Office. (2018). Key short-term economic indicators. National Accounts. Retrieved 5 December 2018 from, https://www.cso.ie/indicators/ Maintable.aspx.

Irish Department of Children and Youth Affairs. (2013a). Press release on child and family Agency Bill 2013. Retrieved 5 December 2018, from https://www.dcya.gov.ie/docs/EN/Press-Releases-copy-dcya-gov-ie-2018/81/2754.htm.

Irish Department of Children and Youth Affairs. (2013b). Child and family agency bill 2013: Regulatory impact analysis. Retrieved 5 December 2018, from https://www.dcya.gov.ie/documents/chidfamilysupportagency/RIA_CFA.pdf.

Irish Department of Finance. (2010). Strengthening the capacity of the Department of Finance: The Wright report. Retrieved 6 December 2018, from https://www. finance.gov.ie/wp-content/uploads/2017/10/reviewdept.pdf.

Irish Institute of Public Administration. (2017). Case study on Tusla: The child and family agency. Retrieved 6 December 2018, from https://www.per.gov.ie/wp-content/uploads/Tusla-IPA-Final-Print-Version-26-Sep-2017-002.pdf.

Jun, J. S. (2009). The limits of post-new public management and beyond. Public Administration Review. 69(1): 161-165.

Kephart, G. \& Asada, Y. (2009). Need-based resource allocation: different need indicators, different results? BMC Health Services Research. 9(1): 122.

Laeven, L. \& Valencia, F. (2012). Systemic banking crises database: An update. International Monetary Fund. Working Paper No. 12/163. Retrieved 5 December 2018, from https://www.imf.org/en/Publications/WP/Issues/2016/12/31/SystemicBanking-Crises-Database-An-Update-26015.

Lodge, M. \& Gill, D. (2011). Toward a new era of administrative reform? The myth of post-NPM in New Zealand. Governance. 24(1): 141-166.

MacCarthaigh, M. (2017). Public sector reform in Ireland: Countering crisis. Cham: Springer International Publishing.

McKevitt, D. \& Lawton, A. (1994). Public sector management: Theory, critique and practice. London: Thousand Oaks, Sage.

OECD. (2010). Making reform happen: Lessons from OECD countries. Paris: OECD Publishing. Retrieved 6 December 2018 , from https://doi.org/10.1787/9789264086296-en.

OECD. (2018). Spending on health: Latest trends. OECD Publishing. Retrieved 6 December 2018, from http://www.oecd.org/health/health-systems/Health-Spending-Latest-Trends-Brief.pdf.

Pane, G. A. \& Taliaferro, E. H. (1994). Health care cost containment: An overview of policy options. Annals of Emergency Medicine. 23(1): 103-108.

Parkes, A., Shore, C., O'Mahony, C. \& Burns, K. (2015). The right of the child to be heard? Professional experiences of child care proceedings in the Irish District Court. Child and Family Law Quarterly. 27(4): 423-44.

Perry, G. (2017). The Practice of Prosecuting Parents for the School Non-Attendance of their Children in Ireland: A Review of Prosecutions made during 2006-2013 under the Education (Welfare) Act 2000. Unpublished doctoral thesis. Retrieved 7 March 2018, from http://doras.dcu.ie/21980/1/Perry_2017_The_Practice_of__Prosecuting_Parents_for_the_School_NonAttendance_of_their_Children.pdf.

Porter, M. (1985). Competitive advantage creating and sustaining superior performance. New York: The Free Press.

Porter, M. \& Teisbers, E., O. (2006). Redefining health care: Creating value-based competition on results. Boston: Harvard Business School Press.

Regling, K. \& Watson, M. (2010). A preliminary report on the sources of Ireland's banking crisis. OH :Government Publications Office Dublin.

Ross, K. \& Levacic, E. (1999). Needs-based resource allocation in education via formula funding of schools. Paris: UNESCO/IIEP.

Smith, K. (2019). Better with Less: (Re) governmentalizing the government of childhood. International Journal of Sociology and Social Policy. 39(1/2): 68-83.

StataCorp, L. P. (2014). Stata Statistical Software: Release 14. College Station, TX: StataCorp LLC.

Tusla. (2018). Welcome to the child and family agency website. Retrieved 6 December 2018 from, https://www.tusla.ie/about/.

White, P., Hodges, A. \& Greenslade, M. (2015). Measuring and maximising value for money in social protection systems: London, UK Department for International Development (DFID). Retrieved 6 July 2018, from http://r4d.dfid.gov.uk/pdf/outputs/ChronicPoverty/61479_ValueForMoneyInSocialProtectionSystems_24Nov2015.pdf.

Whitehead, C. M. E. (1991). From need to affordability: An analysis of UK housing objectives. Urban Studies. 28(6): 871-887.

Williams, D. W., Whelan, C. T. \& Bertrand Maître, J. (2017). The experience of economic stress among families with children during the Irish recession. ESRI Research Bulletin. Retrieved 6 December 2018, from https://www.esri.ie/pubs/RB20170404.pdf.

\section{ACKNOWLEDGMENT}

Funding for this project was received from the Irish Research Council (IRC) in partnership with the Child and Family Agency - Tusla. 
Walsh et al.

Appendix-I

\begin{tabular}{lccccc}
\hline \multicolumn{1}{c}{ Variables } & n & Mean & Std. Dev. & Min & Max \\
\hline Log member firm billed (Euros) & 1032 & 7.092 & 1.399 & 2.752 & 10.72 \\
Dublin Mid Leinster & 1032 & 0.328 & 0.470 & 0 & 1 \\
Dublin North East & 1032 & 0.217 & 0.412 & 0 & 1 \\
South & 1032 & 0.190 & 0.392 & 0 & 1 \\
West & 1032 & 0.266 & 0.442 & 0 & 1 \\
Partner & 1032 & 0.609 & 0.488 & 0 & 1 \\
Solicitor & 1031 & 0.334 & 0.472 & 0 & 1 \\
Associate & 1032 & 0.539 & 0.499 & 0 & 1 \\
Adoption & 1032 & 0.026 & 0.182 & 0 & 2 \\
Adoption domestic & 1032 & 0.002 & 0.044 & 0 & 1 \\
Appeals from Orders to Circuit Court & 1032 & 0.056 & 0.293 & 0 & 3 \\
Care Order Section 18 & 1032 & 0.402 & 0.702 & 0 & 3 \\
Child Abduction & 1032 & 0.050 & 0.307 & 0 & 3 \\
Cost negotiation & 1032 & 0.078 & 0.333 & 0 & 3 \\
Criminal proceedings & 1032 & 0.086 & 0.381 & 0 & 3 \\
Directions Hearing & 1032 & 0.045 & 0.216 & 0 & 2 \\
Disclosure Criminal & 1032 & 0.041 & 0.238 & 0 & 3 \\
Emergency Care Order Section13 & 1032 & 0.282 & 0.544 & 0 & 2 \\
Foster care & 1032 & 0.024 & 0.160 & 0 & 2 \\
Fostering to Adoption & 1032 & 0.009 & 0.135 & 0 & 3 \\
General Advice & 1032 & 0.296 & 0.577 & 0 & 3 \\
Interim Care Order Section 17 & 1032 & 0.522 & 0.801 & 0 & 3 \\
Juvenile Matters & 1032 & 0.028 & 0.182 & 0 & 2 \\
Residential Care & 1032 & 0.006 & 0.076 & 0 & 1 \\
Section 20 directions & 1032 & 0.058 & 0.279 & 0 & 2 \\
Section 25 Mental Health Act 2001 & 1032 & 0.006 & 0.076 & 0 & 1 \\
Section 3 investigations & 1032 & 0.040 & 0.219 & 0 & 3 \\
Section 47 applications & 1032 & 0.113 & 0.373 & 0 & 3 \\
Special care order & 1032 & 0.045 & 0.295 & 0 & 3 \\
Supervision Order Section 19 & 1032 & 0.282 & 0.598 & 0 & 3 \\
Variation/discharge order section 22 & 1032 & 0.044 & 0.227 & 0 & 2 \\
\hline Sor AxLE(2016 & & & & &
\end{tabular}

Source: AXLE (2016)

Table 1. Descriptive Statistics 


\begin{tabular}{|c|c|}
\hline & Y=Log Member Firm Billed \\
\hline & b(se) \\
\hline \multicolumn{2}{|l|}{ LSU Admin Area } \\
\hline Dublin Mid-Leinster & $0.149(0.089)$ \\
\hline South & $0.149(0.106)$ \\
\hline West & $0.055(0.098)$ \\
\hline \multicolumn{2}{|l|}{ Fee-earner Type } \\
\hline Partner & $0.417^{* * *}(0.084)$ \\
\hline Solicitor & $-0.131(0.081)$ \\
\hline Associate & $0.212^{* *}(0.080)$ \\
\hline \multicolumn{2}{|l|}{ Legal Category - Number of } \\
\hline Adoption & $1.250^{* * *}(0.187)$ \\
\hline Adoption domestic & $1.663^{*}(0.755)$ \\
\hline Appeals from Orders to Circuit Court & $0.174(0.116)$ \\
\hline Care Order Section 18 & $0.474^{* * *}(0.051)$ \\
\hline Child Abduction & $0.482^{* * *}(0.118)$ \\
\hline Cost negotiation & $0.193(0.112)$ \\
\hline Criminal proceedings & $0.708^{* * *}(0.089)$ \\
\hline Directions Hearing & $0.271(0.150)$ \\
\hline Disclosure Criminal & $0.526^{* * *}(0.135)$ \\
\hline Emergency Care Order Section 13 & $0.222^{* * *}(0.062)$ \\
\hline Foster Care & $-0.149(0.199)$ \\
\hline Fostering to Adoption & $0.448(0.251)$ \\
\hline General Advice & $0.129^{*}(0.062)$ \\
\hline Interim Care Order Section 17 & $0.604^{* * *}(0.047)$ \\
\hline Juvenile Matters & $0.262(0.177)$ \\
\hline Residential Care & $0.227(0.431)$ \\
\hline Section 20 directions & $0.006(0.115)$ \\
\hline Section 25 Mental Health Act 2001 & $0.908^{*}(0.411)$ \\
\hline Section 3 investigations & $0.332 *(0.146)$ \\
\hline Section 47 applications & $0.151(0.087)$ \\
\hline Special Care Order & $0.572^{* * *}(0.131)$ \\
\hline Supervision Order Section 19 & $0.503^{* * *}(0.057)$ \\
\hline Variation/Discharge Order Section 22 & $0.404^{* *}(0.148)$ \\
\hline Constant & $5.660^{* * *}(0.101)$ \\
\hline $\mathrm{n}$ & 1032 \\
\hline $\operatorname{Adj} R^{2}$ & 0.497 \\
\hline
\end{tabular}

Table 2. OLS Regression Results: Member Firm Billed (Euros) 